УДК 332.2:528.9:004.01

\title{
CONCEPTUAL APPROACHES TO THE FORMATION OF AN AUTOMATED SYSTEM OF MANAGEMENT OF THE LAND AND PROPERTY COMPLEX OF THE NATIONAL ACADEMY OF AGRARIAN SCIENCES OF UKRAINE
}

Novakovsky L., Doctor of Economics, Professor, Academician of NAAS Presidium of the National Academy of Agrarian Sciences of Ukraine E-mail: leonidnovakovsky01@gmail.com

Dorosh J., Doctor of Economics E-mail:dorosholgas@ukr.net Tarnopolsky A., E-mail: andrey0037@gmail.com

Ibatullin S., Doctor of Economics, Professor, Corresponding Member of NAAS E-mail: shamilibatullin@gmail.com

Institute of Land Management of the National Academy of Agrarian Sciences of Ukraine

The importance of creation and improvement of the automated system of management of the land and property complex of the National Academy of Agrarian Sciences of Ukraine is substantiated. The principles and standards of national geospatial data infrastructure are emphasized.

The following are the main components of the automated system of land and real estate management of NAAS: object composition of data, roles and levels of access to the system, data protection and information security, business processes and functionality, spatial and organizational structure, data quality, retrospect, data analysis and reporting, planning and vision, etc.

There are several subject blocks of business processes of managing the objects of the NAAS land and property complex: determination of the legal status and ensuring control over the observance of the legal regime of the use of land resources 
and real estate; research and experimental development; production, economic, service and support processes; monitoring, analysis and reporting; interaction with other services and interoperability of data; verification and validation of data.

Among the main tasks of the system: geoinformation database of real rights to real estate and their restrictions, inventory and monitoring of land resources, forming of agricultural land, accounting for particularly valuable land, zoning and zoning, etc.

When considering approaches to the formation of the automated system, the peculiarities of the research and educational purpose of the NAAS land and property complex and its importance for the national security of the country are taken into account.

Keywords: land and property complex, land resources, real estate, automated control systems, geospatial data infrastructure, state property, land management, land cadastre, information and analytical system.

Formulation of the problem. The National Academy of Agrarian Sciences of Ukraine (hereinafter referred to as NAAS) manages research institutes, other scientific institutions, organizations, enterprises (research stations, research farms, botanical gardens, arboretums, reserves, libraries, museums, etc.), objects of the social sphere [1] (hereinafter referred to as objects of the land and property complex).

The objects of the land and property complex of the NAAS of Ukraine belong to it under the right of economic management and are transferred to organizations, which are under the jurisdiction of the NAAS, under the right of operational management [2].

In performing the authority to manage the objects of the land complex, the NAAS should ensure that the rights of the state as the owner of these objects are managed and effectively used. Among the functions of managing the objects of the NAAS land and property complex are accounting and control over the efficiency of their use [3]. 
Components of the material base of NAAS institutions are land, buildings, structures, long term plantations, communications, equipment, vehicles, office accommodation and other assets, intangible assets. At the same time, the specifics of managing the property complex of the NAAS are characterized by the peculiarities of the use of land resources as a basic means in research, production and economic activity.

According to the land legislation, the research fields of NAAS institutions refer to particularly valuable lands [4]. That fact increases the role and responsibility of managing the use of objects of the Academy's land and property complex. Land resources and real estate in the NAAS are one of the most important prerequisites for achieving its statutory goals and objectives, one of which is to ensure the country's food security.

All of the above indicates the importance of creation and improvement of the automated informational system of NAAS land and property complex management, which in modern conditions should be based on ideology of geospatial data infrastructure and automation of administrative processes.

The purpose of the study is to determine the basic approaches and requirements for the structure and processes of the automated system of management of land and property complex of the National Academy of Agrarian Sciences of Ukraine.

Results of the study and discussion. Taking into account the international and domestic experience of using modern information-analytical systems of the appropriate level, as well as the specifics of NAAS activity, we propose the following conceptual approaches to the formation and improvement of the automated system of management of the NAAS land and property complex (hereinafter - ASM).

1. Standards. The ASM is based on the principles and standards of the National Spatial Data Infrastructure (NSDI) and the European Union Spatial Data Infrastructure, implemented at the initiative of the European Commission and regulated by the INSPIRE Directive. 
2. Object schema of the data. According to NSDI, the information system includes the following components: basic and profile sets of geospatial data, metadata and their catalogs, geoinformational services, means of generating and updating geospatial data, interoperability and providing access to them $[6,7]$.

In general, the information of ASM can be divided into spatial and attributive. Spatial information includes raster (topographic basis, aerial images and remote sensing data, maps of agricultural production groups of soils, land management projects, forest management, etc.) and vector data [digital topographic and thematic maps, land parcels boundaries, research fields, real world objects (topographic objects), boundaries of land protection and sanitary protection zones, etc.]. Attribute data characterizes the quantitative and qualitative parameters of NAAS objects and territories, including statistical, administrative, economic, organizational data types, such as cadastral data on real estate, street registers, addresses, etc.

The institutions, enterprises and organizations of the NAAS network (Fig. 1), presented in the ASM, correspond to the actual data of the Unified State Register of Legal Entities, Individual Entrepreneurs and Public Formations, as well as contain information specific to the NAAS, which characterizes its internal organizational structure. In the absence of online access to national registers and data exchange, the ASM should also contain business processes for updating data related to the NAAS land parcels and land rights.

3. Roles and levels of access. Access to data and processes in the ASM is provided according to hierarchical relations by levels: Academy Presidium, Departments, Regional Centers, National Research Centers, Institutes, Research Stations and State Research Enterprises. The functions and granting of authorities are also distributed by several levels of system users and administrators.

4. Protection of information. Given the nature of the data contained in the ASM, its integral part is a comprehensive system of information protection in accordance with the current legislation of Ukraine. 


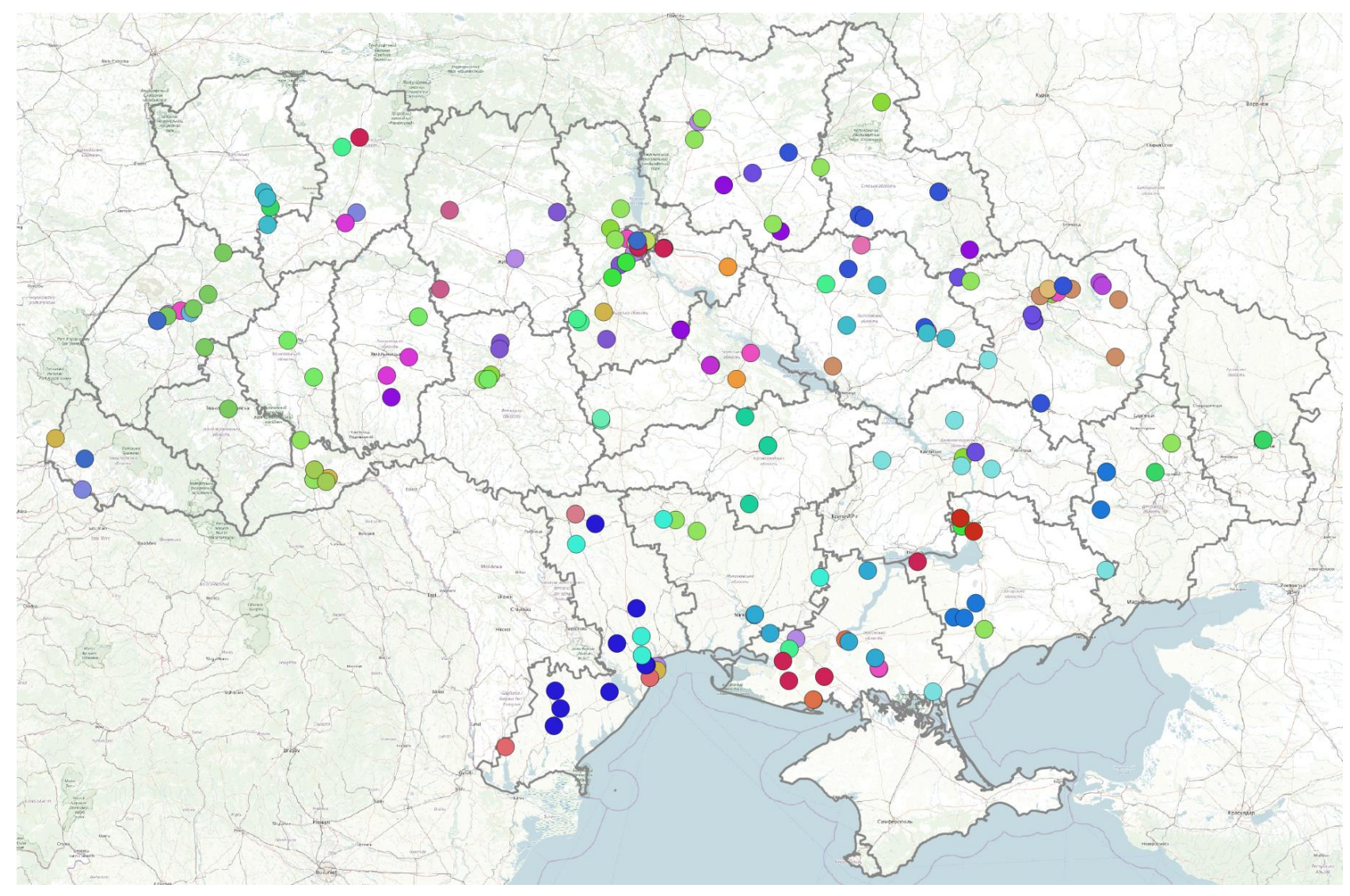

Fig. 1. Location of NAAS institutions, enterprises and organizations.

4. Business processes. There are several subject blocks of business processes in the structure of the ASM, which are aimed at managing the objects of the NAAS land and property complex: determining the legal status and ensuring control over compliance with the legal regime of use of land resources and real estate; research and experimental development; production, economic, service and support processes; monitoring, analysis and reporting; interaction with other services and interoperability of data, verification and validation of data. Requirements for functional specifications of an automated system, including reengineering of business processes of property management, must be identified and generalized. Thus, among the main tasks of the system: geoinformation database of rights and restrictions to real estate, monitoring of land resources, agricultural land use planning, accounting for particularly valuable land, zoning, etc.

5. Spatial structure. The complexity of the automated system will allow comprehensive coverage of the objects of the land and property complex in different 
sections: functional zoning; economic, agro-ecological zoning; establishment of quarantine, buffer, sanitary and protection zones, ecological restrictions, boundaries of these zones and factors of influence, etc.

6. Data collection and data quality. For the purposes of ensuring the accuracy and relevance of the data, some of them are collected through the automatic services of public registers of Ukraine. However, it should be noted that such services still need to be improved in terms of datasets, their types, and service interaction processes. The ASM provides the tools for regular updating of data (with some discretion) on the basis of interaction with public state data services. Part of the data is entered into ASM by primary (basic) users at the level of enterprises, institutions and Branches of Academy. This information is validated and verified for errors and discrepancies by the ASM tools. However, a significant amount of primary data must be inputted and processed by a qualified personnel of the ASM Administrator. As a result of continuous monitoring and inventory of land and real estate, violations and inconsistencies will be identified and eliminated, which will make it possible to conform the legal status of the property and the regime of its economic use.

7. Functionality of ASM. The most important task of the ASM, as an information-analytical system, is to provide information on the processes of managing the land and property complex for the fulfillment of NAAS main functions in academic research. In particular, it is about the formation of land resources as objects of management of research and production and economic activity, by defining the boundaries of research fields, research parcels, demonstration landfills, types of land, crops and their comprehensive evaluation.

It is necessary to display information on the status of crops, varieties of crops, fertilizers, plant protection products, agricultural machinery, technological operations. Heterogeneous information should be harmonized in a user-friendly way, such as comparing remote sensing data from land to land boundaries, maps for transport management and agricultural machinery, which can be compared to other maps, such as the spread of pests, diseases and weeds, thematic maps of gross and commodity crop production, maps of agricultural production groups of soils, etc. 
8. Retrospective. All changes in the data are recorded separately in the timeline so that they can compare the dynamics of such changes. Thus, in the history of the fields are recorded the alternation of crops, volumes of fertilizers, materials, meteorological data, etc. It is of particular value for conducting research, making experiments and analyzing their results. Detailed retrospective information is also needed, for example, for certification of fields for organic farming.

9. Analysis and reporting. The accumulation and processing of actual, reliable, comprehensive information about the objects of the land and property complex is achieved by improvement of control and analysis forms for the purposes of making management decisions, which will be a component of management accounting. Formalized analytical requests on the land availability and use of property show the level of economic efficiency of research and production activity by the centers of responsibility, innovation-investment projects and types of innovative products of the NAAS network. And formalized analytical research requests in the areas of NAAS structural units will allow their results to be used in interdisciplinary research.

The use of spatial analysis techniques on such amount of data opens up considerable opportunities for the study of factors of influence and the identification of patterns. The large volume of data covering different regions of Ukraine, different natural and climatic conditions and different technologies makes it possible to use modern methods of factor and spatial analysis.

10. Planning and strategy. The ASM is based on the need to provide the data management system for the Academy's development strategy, long-term and annual plans of its institutions and enterprises. It will allow specifying the scientific and industrial specialization of enterprises, creating crop rotations in different natural and climatic conditions, improving methods and forms of land use, developing new technological techniques. The use of automatic control systems in the planning of research and agricultural production as part of management accounting will ensure high accuracy of planning the use of fuel, seeds, fertilizers, plant protection products, distribution of agricultural machinery in crop rotation fields, and, accordingly, reducing the cost of production. The functionality of the ASM will serve as a basis for 
modeling and predicting spatial development. The implementation of the recommendations the INSPIRE Directive will give an opportunity the integration of Ukrainian agrarian science into the international scientific community.

11. The stages of ASM development include: the concept, requirements for technical specifications, technical specifications, project development, project implementation, pilot operation and implementation into production.

12. Software. Open source software is used to develop and maintain the ASM.

Conclusions. Modern world and domestic experience testifies to widespread use of geoinformation technologies for land management, real estate objects, economic infrastructure in large corporations, territorial communities, settlements and regions.

Formation and improvement of the automated system of management of the land complex of NAAS of Ukraine is an important stage of creation of a platform for transition to digital data and digital processes not only in the management of the land and property complex of NAAS, but also in agrarian science, which will ensure efficient use of state property and fulfillment of statutory of the Academy's tasks.

The implementation of this system will help to increase transparency in the use of objects of land and property complex at all levels. It is also an important step in implementing the principle of combining science, business, the manufacturer and the consumer of innovative products. The openness of some of the data in this system can serve as a platform for spreading best practices for domestic agricultural producers.

The development of this system is a step towards the creation of a unified innovative product for the market of agricultural producers of different forms of ownership and management.

\section{References}

1. Statute of the National Academy of Agrarian Sciences of Ukraine. Available at: http://naas.gov.ua/content/statut-naan. 
2. Zakon Ukrayiny vid 07.02.2002 № 3065-III «Pro osoblyvosti pravovoho rezhymu diyal $\square$ nosti Natsional $\square$ noyi akademiyi nauk Ukrayiny, natsional $\square$ nykh haluzevykh akademiy nauk ta statusu yikh maynovoho kompleksu» [The law of Ukraine of February 07, 2002 № 3065-III «On the peculiarities of the legal regime of activity of the National Academy of Sciences of Ukraine, national sectoral academies of sciences and the status of their property complex»]. (2002). Vidomosti Verkhovnoyi Rady Ukrayiny - Bulletin of the Verkhovna Rada of Ukraine, 30, 205 [in Ukrainian].

3. Zakon Ukrayiny vid 26.11.2015 № 848-VIII «Pro naukovu i naukovotekhnichnu diyal $\square$ nist $\square$ 》 [The law of Ukraine of November 26, 2015 № 848-VIII «On scientific and scientific-technical activity»]. (2015). Vidomosti Verkhovnoyi Rady Ukrayiny - Bulletin of the Verkhovna Rada of Ukraine, 3, 25 [in Ukrainian].

4. Zakon Ukrayiny vid 25.10.2001 № 2768-III «Zemel $\square$ nyy kodeks Ukrayiny» [The law of Ukraine of October 26, 2001 № 2768-III «Land Code of Ukraine»]. (2001). Vidomosti Verkhovnoyi Rady Ukrayiny - Bulletin of the Verkhovna Rada of Ukraine, 3, 27 [in Ukrainian].

5. Zakon Ukrayiny vid 07.07.2011 № 3613-VI «Pro Derzhavnyy zemel $\square$ nyy kadastæ» [The law of Ukraine of July 7, 2011 № 3613-VI «On the State Land Cadastre»]. (2012). Vidomosti Verkhovnoyi Rady Ukrayiny - Bulletin of the Verkhovna Rada of Ukraine, 8, 61 [in Ukrainian].

6. Dishlik, O. P., Dorosh, A. Y., Tarnopolsky, A. V., Tarnopolsky, E. A. (2018). Infrastruktura heoprostorovykh danykh $v$ Ukrayini: stan ta metodolohichni problemy zakonodavchoho rehulyuvannya [Geospatial data infrastructure in Ukraine: position and methodological problems of legislative regulation]. Land management, cadastre and land monitoring, 1, 33-43 [in Ukrainian].

7. Tarnopolsky, A. V., Malashevsky, M. A., Tarnopolsky, E. A., Palamar, A. Y. (2018). Deyaki aspekty pobudovy infrastruktury heoprostorovykh danykh [Some aspects of a geospatial data infrastructure creation]. Young scientist, 2 (54), 28 - 31 [in Ukrainian]. 
Новаковський Л.Я., Дорош Й.М., Тарнопольський А.В., Ібатуллін U.I.

Концептуальні підходи до формування автоматизованої системи управління земельно-майновим комплексом Національної академії аграрних наук України

Обтрунтовано важливість створення та удосконалення автоматизованої системи управління земельно-майновим комплексом Національної академії аграрних наук України. Наголошено на необхідності врахування принципів $і$ стандартів національної інфраструктури геопросторових даних.

Наведено такі основні складові автоматизованої системи управління земельними ресурсами та нерухомістю НААН: об'єктний склад даних, ролі та рівні доступу до системи, захист інформації, бізнес-процеси та функиіональність, просторова та організаційна структура, якість даних, ретроспектива, аналіз даних та звітність, планування тощо.

Запропоновано виділити декілька предметних блоків бізнес-процесів, на які спрямоване управління об'єктами земельно-майнового комплексу НААН: визначення правового статусу та забезпечення контролю за дотриманням правового режиму використання земельних ресурсів та нерухомого майна; науково-дослідні роботи та експериментальні розробки; виробничогосподарські, обслуговуючі та допоміжні прочеси; моніторине, аналіз та звітність; взаємодія з іншими сервісами та інтероперабельність даних, верифікачія та валідачія даних.

Серед основних завдань системи: геоінформаиійна база даних речових прав на нерухоме майно та їх обмежень, інвентаризація та моніторинг земельних ресурсів, упорядкування сільськогосподарських угідь, облік особливо цінних земель, зонування та районування тощо.

При розгляді підходів до формування зазначеної автоматизованої системи враховано особливості науково-дослідного та навчального 
призначення земельно-майнового комплексу НААН $і$ його важливість для національної безпеки країни.

Ключові слова: земельно-майновий комплекс, земельні ресурси, нерухомість, автоматизовані системи управління, інфраструктура геопросторових даних, державна власність, землеустрій, земельний кадастр, інформачійно-аналітична система.

\section{Новаковский Л.Я., Дорош Й.М., Тарнопольский А.В., Ибатуллин Ш.И.}

Концептуальные подходы к формированию автоматизированных систем управления земельно-имущественным комплексом Национальной академии аграрных наук Украины

Обоснована важность создания и совершенствования автоматизированной системы управления земельно-имущеетвенным комплексом Нациинальной академии аграрных наук Украиньл. Отмечена необходимость учета принциипов и стандартов национальной инфраструктурьл геопространственных данных.

Приведены следующие основные составляющче автоматизированной системь управления земельными ресурсами и недвижимостью НААН: объектный состав данных, роли и уровни доступа к системе, защзита информации, бизнес-проичессыл и функциональность, пространственная $u$ организационная структура, качество данных, ретроспектива, анализ данных и отчетность, планирование и др.

Предложено выделить несколько предметных блоков бизнес-процессов, на которые направлено управления объектами земельно-имущественного комплекса НААН: определение правового статуса и обеспечения контроля за соблюдением правового режима использования земельных ресурсов $и$ недвижимого имущества; научно-исследовательские работьи $и$ экспериментальные р разработки; производственно-хозяйственные, обслуживающие и вспомогательные процессы; мониторинг, анализ и 
отчетность; взаимодействие с другими сервисами и интероперабельность данных, верификация и валидацчия данных.

Среди основных задач системы: геоинформаџчинная база данных прав на недвижимое имущуество и их ограничений, инвентаризациия и мониторинг земельных ресурсов, упорядочение сельскохозяйственных угодий, учет особо цеенных земель, зонирование и районирование и др.

При рассмотрении подходов к формированию указанной автоматизированной системы учтены особенности научноисследовательского и учебного назначения земельно-имущуественного комплекса НААН и его значение для нащчональной безопасности страньл.

Ключевые слова: земельно-имущуественный комплекс, земельные ресурсы, недвижимость, автоматизированные системы управления, инфраструктура геопространственных данных, государственная собственность, землеустройство, земельный кадастр, информационно-аналитическая система. 